\title{
PENGARUH ASUPAN MAKAN (ENERGI, KARBOHIDRAT, PROTEIN DAN LEMAK) TERHADAP DAYA TAHAN JANTUNG PARU (VO 2 MAKS) ATLET SEPAK BOLA
}

\author{
Arum Bunga Pertiwi, Etisa Adi Murbawani ${ }^{*}$ \\ Program Studi Ilmu Gizi Fakultas Kedokteran Universitas Diponegoro \\ Jl.Dr.Sutomo No.14, Semarang, Telp (024) 8453708, Email : gizifk@ undip.ac.id
}

\begin{abstract}
Background : The balance intake of nutrients affect on athletes performance on a match. In general, a soccer player requires the fulfillment of energy, carbohydrate, protein and fat with considering exercise and daily physical activity.

Purpose : The purpose of this study was to verify the effect of food intake (energy, carbohydrate, protein and fat) on cardiorespiratory endurance $\left(\mathrm{VO}_{2}\right.$ max) of soccer athletes.

Methods : Quasi-experimental study with an approach of one group pre and post test design at 19 athletes aged 1418 years in Pusat Pendidikan Latihan Pelajar (PPLP) Central Java in June 2012. During the eleven days, the subjects were given foods with $55-60 \%$ carbohydrate, $15-20 \%$ protein and $20-30 \%$ fat of the total energy requirement or energy expenditure per day. The measurement of cardiorespiratory endurance was measured by Cooper Test method.

Results: Intakes of energy, carbohydrate, protein, and fat had no effect on cardiorespiratory endurance with $p$ value $>0,05$.

Conclusion : Intakes of energy, carbohydrate, protein and fat have no effect on cardiorespiratory endurance of soccer athletes. Cardiorespiratory endurance effected by body mass index.
\end{abstract}

Key words: food intake; cardiorespiratory endurance; soccer athletes

\begin{abstract}
ABSTRAK
Latar Belakang : Asupan zat gizi yang seimbang dapat mempengaruhi performa seorang atlet pada saat bertanding. Secara umum pemain sepak bola memerlukan pemenuhan energi, karbohidrat, protein dan lemak dengan mempertimbangkan latihan dan aktivitas fisik sehari-hari.

Tujuan : Penelitian ini bertujuan untuk mengetahui pengaruh asupan makan (energi, karbohidrat, protein dan lemak) terhadap daya tahan jantung paru ( $\mathrm{VO}_{2}$ maks) atlet sepak bola.

Metode : Studi eksperimental quasi dengan pendekatan one group pre and post test design pada 19 atlet sepak bola berusia 14-18 tahun di Pusat Pendidikan dan Latihan Pelajar Jawa Tengah pada bulan Juni 2012. Selama sebelas hari subjek diberi makanan yang terdiri dari 55-60\% karbohidrat, 15-20\% protein dan 20-30\% lemak dari total kebutuhan atau pengeluaran energi per hari. Pengukuran daya tahan jantung paru dilakukan dengan metode Cooper Test.

Hasil : Asupan energi, karbohidrat, protein dan lemak tidak berpengaruh terhadap daya tahan jantung paru dengan nilai $p>0,05$.

Simpulan : Asupan energi, karbohidrat, protein dan lemak tidak berpengaruh terhadap daya tahan jantung paru atlet sepak bola. Daya tahan jantung paru dipengaruhi oleh indeks massa tubuh.
\end{abstract}

Kata kunci : asupan makan; daya tahan jantung paru; atlet sepak bola

\section{PENDAHULUAN}

Permainan sepak bola merupakan salah satu olahraga endurance beregu yang membutuhkan daya tahan jantung paru. Kesegaran jasmani yang rendah diikuti dengan penurunan daya tahan jantung paru dapat menyebabkan penurunan kecepatan dan keterampilan dalam bermain bola. ${ }^{1}$ Daya tahan jantung paru dapat diukur melalui kadar $\mathrm{VO}_{2}$ maksimal yang dicapai. $\mathrm{VO}_{2}$ maksimal merupakan jumlah maksimum oksigen yang dapat diambil selama melakukan olahraga. $^{2}$ Hasil penelitian menunjukkan bahwa atlet dengan nilai $\mathrm{VO}_{2}$ maksimal sebesar 80 $\mathrm{mL} / \mathrm{kg} \mathrm{BB} / \mathrm{menit}$ dapat berlari $5000 \mathrm{~m}$ lebih cepat dibandingkan dengan atlet yang hanya memiliki nilai $\mathrm{VO}_{2}$ maksimal sebesar $40 \mathrm{~mL} / \mathrm{kg} \mathrm{BB} /$ menit. $^{3}$ Semakin tinggi nilai $\mathrm{VO}_{2}$ maksimal maka semakin baik pula daya tahan jantung paru, sehingga atlet cabang olahraga endurance dengan daya tahan jantung paru yang baik maka prestasinya akan lebih baik. ${ }^{4}$ 
Daya tahan jantung paru yang baik dapat diperoleh melalui status gizi yang baik pula, dimana status gizi merupakan keadaan tubuh atau keadaan kesehatan yang diakibatkan dari hasil keseimbangan asupan makanan, penyerapan dan penggunaan zat gizi. ${ }^{5}$ Status gizi yang baik dapat diperoleh melalui asupan makan yang seimbang. ${ }^{6}$ Asupan zat gizi yang seimbang mempengaruhi penampilan prima seorang atlet pada saat bertanding. ${ }^{7}$ Konsumi energi dan zat gizi yang kurang atau melebihi kebutuhan umumnya akan memberikan efek yang kurang baik terhadap fungsi fisiologis tubuh. ${ }^{8}$ Hasil penelitian di Bali menunjukkan dari 26 sampel, $22(86,4 \%)$ atlet mengkonsumsi energi sesuai dengan kebutuhan dan memiliki nilai $\mathrm{VO}_{2}$ maksimal yang telah memenuhi standar. Sisanya sebanyak $4(15,4 \%)$ atlet mengkonsumsi energi kurang dari kebutuhan dan mereka memiliki nilai $\mathrm{VO}_{2}$ maksimal kurang dari standar. ${ }^{6}$

Secara umum seorang pemain sepak bola memerlukan pemenuhan energi sesuai kebutuhan dengan kandungan karbohidrat sebesar $55-60 \%$ dari total energi, lemak $20-30 \%$ dari total kebutuhan energi, dan protein $15-20 \%$ dari total kebutuhan energi. ${ }^{7}$ Bagi pemain sepak bola, energi yang dikeluarkan untuk berolahraga harus seimbang dengan energi yang masuk dari makanan. ${ }^{1}$

Konsumsi makanan yang optimal akan menghasilkan energi, sehingga kemampuan kerja dan waktu pemulihan menjadi lebih baik. ${ }^{6}$ Asupan gizi yang seimbang juga digunakan untuk memperbaiki dan mempertahankan status gizi, membentuk otot, mencapai tinggi badan yang optimal, memelihara kondisi tubuh serta menjaga kesegaran jasmani. ${ }^{1}$

Indonesia memiliki banyak tempat pelatihan sepak bola, salah satunya yaitu Pusat Pendidikan Latihan Pelajar (PPLP) Jawa Tengah di Salatiga. PPLP merupakan tempat pembinaan atlet berasrama, dimana beberapa atlet telah menunjukkan prestasi. Pada tahun 2009 Juara 2 Pekan Olahraga Pelajar Nasional di Yogyakarta, tahun 2010 Juara 2 Kejuaraan Nasional antar Diklat di Medan dan Juara 1 Pekan Olahraga Pelajar Wilayah, tahun 2011 Juara 1 Kejuaraan Nasional di Semarang, dan Juara 2 Pekan Olahraga Pelajar Nasional di Pekanbaru, tahun 2012 Juara 1 Kejuaraan Nasional di Papua.

Umumnya asrama sepak bola dapat lebih menjamin asupan gizi, namun dari hasil penelitian sebelumnya di PPLP Salatiga menunjukkan bahwa masih terdapat atlet yang mengalami defisiensi energi yakni dari 20 sampel penelitian yang memiliki kategori defisiensi tingkat berat sebanyak 14 orang $(70 \%)$ dan yang memiliki kategori defisiensi tingkat sedang sebanyak 6 orang $(30 \%){ }^{9}$ Adanya kejadian defisiensi energi di PPLP tersebut menarik minat peneliti untuk menjadikan PPLP sebagai tempat penelitian.

Penelitian ini bertujuan untuk mengetahui pengaruh asupan makan terhadap daya tahan jantung paru atlet sepak bola, serta mendeskripsikan dan menganalisis faktor lain yang dapat mempengaruhi daya tahan jantung paru yaitu status gizi (IMT), persen lemak tubuh, dan kadar hemoglobin pada atlet sepak bola.

\section{METODE PENELITIAN}

Penelitian ini merupakan penelitian eksperimental quasi dengan rancangan one group pre and post test design dan termasuk dalam ruang lingkup keilmuan gizi masyarakat. Penelitian dilakukan di Pusat Pendidikan Latihan Pelajar (PPLP) Salatiga pada bulan Juni 2012. Subjek penelitian ini adalah atlet sepak bola di PPLP yang diperoleh melalui metode consecutive sampling, dimana subjek yang memenuhi kriteria dimasukkan dalam penelitian hingga jumlah subjek yang diperlukan terpenuhi. ${ }^{10}$ Besar subjek minimal yang diperlukan dalam penelitian ini yaitu 17 orang.

Variabel bebas pada penelitian ini adalah asupan makan (energi, karbohidrat, protein, dan lemak). Variabel kontrol pada penelitian ini adalah indeks massa tubuh, persen lemak tubuh, dan kadar hemoglobin. Variabel terikat pada penelitian ini adalah daya tahan jantung paru atlet sepak bola. Daya tahan jantung paru diukur menggunakan metode Cooper Test yakni lari selama 12 menit pada lintasan lari 400 meter untuk mengetahui nilai $\mathrm{VO}_{2}$ maksimal yang diperoleh.

Penelitian ini dilakukan selama 13 hari, dimana dua hari pertama merupakan pre test atau pengambilan data awal berupa food recall, pengukuran antropometri, status gizi, persen lemak tubuh, kadar hemoglobin, dan daya tahan jantung paru. Sebelas hari selanjutnya subjek penelitian mendapat perlakuan berupa pemberian makanan sesuai dengan besar energi yang dibutuhkan sesuai dengan besarnya energi yang dihitung berdasar range kebutuhan asupan atlet. Kebutuhan energi diperoleh dengan mempertimbangkan Basal Metabolism Rate (BMR), Specific Dynamic Action (SDA), pertumbuhan, serta aktivitas baik latihan sepak bola maupun diluar latihan. ${ }^{1} \quad$ Rata-rata asupan makan yang diberikan selama sebelas hari 
adalah energi sebesar 4432,6 kkal, karbohidrat $678,8 \mathrm{~g}$, protein $136,7 \mathrm{~g}$ dan lemak 146,6 g. Pemberian makanan dalam sehari dibagi menjadi tiga kali makan utama dan tiga kali snack. Makan utama berupa nasi atau mie, lauk nabati, lauk hewani, sayur, dan buah, sedangkan snack berupa kue dan jus. Pada hari ketiga belas dilakukan kembali pengukuran status gizi, persen lemak tubuh, kadar hemoglobin dan daya tahan jantung paru.

Data yang dikumpulkan meliputi data berat badan, tinggi badan, persen lemak tubuh, indeks massa tubuh, kadar hemoglobin, asupan makan dan pengukuran daya tahan jantung paru. Pengukuran berat badan diperoleh melalui penimbangan menggunakan timbangan injak digital dengan ketelitian $0,1 \mathrm{~kg}$. Pengukuran tinggi badan diperoleh melalui pengukuran menggunakan microtoise dengan batas ukur $200 \mathrm{~cm}$ dan ketelitian $0,1 \mathrm{~cm}$. Persen lemak tubuh didapatkan melalui pengukuran menggunakan Bioelectric Impedance Analyzer (BIA) injak jenis Omron HBF 200. Kadar hemoglobin didapatkan melalui pengukuran dengan cyanmethemoglobin yang dilakukan oleh laboran dari Rumah Sakit Ananda Kota Salatiga. Asupan makan sebelum dan selama perlakuan didapat melalui formulir food recall 24 jam. Waktu yang diperlukan untuk menyelesaikan tes lari yang telah ditentukan diukur menggunakan stopwatch dengan ketelitian 0,01 detik.

Analisis data dilakukan dengan menggunakan program komputer. Analisis univariate untuk mendeskripsikan karakteristik subjek penelitian yaitu usia, tinggi badan, berat badan, indeks massa tubuh, kadar hemoglobin, persen lemak tubuh, asupan makan (energi, karbohidrat, protein, dan lemak), dan daya tahan jantung paru. Analisis bivariate diawali dengan uji kenormalan data Kolmogorov Smirnov, kemudian dilanjutkan dengan uji beda paired t-test untuk data berdistribusi normal, dan uji Wilcoxon untuk data berdistribusi tidak normal, setelah itu dilakukan uji korelasi Pearson untuk melihat hubungan antar variabel. Analisis multivariate menggunakan uji regresi linier ganda yang digunakan untuk melihat pengaruh variabel bebas, dan variabel kontrol terhadap variabel terikat. ${ }^{10}$ Data asupan makan yang diperoleh dari hasil food recall dianalisis dengan bantuan program nutrisurvey.

\section{HASIL PENELITIAN}

Penelitian dilakukan di Pusat Pendidikan Latihan Pelajar (PPLP) Salatiga pada bulan Juni 2012. Subjek penelitian merupakan atlet sepak bola berusia 14-18 tahun di PPLP. Sebanyak 24 orang bersedia menjadi subjek penelitian namun hanya 22 orang yang masuk dalam kriteria inklusi. Selama penelitian terdapat tiga orang yang drop out dikarenakan tidak dapat mengikuti seluruh rangkaian penelitian.

\section{Karakteristik Subjek Penelitian}

Usia subjek pada penelitian ini yaitu 15-18 tahun dengan rerata usia 17,4 $\pm 1,0$ tahun. Rerata tinggi badan dan berat badan subjek yaitu 172,1 \pm $4,2 \mathrm{~cm}$ dan $64,9 \pm 8,1 \mathrm{~kg}$. Rerata kebutuhan energi subjek yaitu 4469,7 $\pm 367,9$ kkal. Distribusi frekuensi karakteristik subjek menurut IMT, persen lemak tubuh, kadar hemoglobin, asupan energi, karbohidrat, protein, lemak, dan daya tahan jantung paru dapat dilihat pada Tabel 1 .

Tabel 1. Distribusi Frekuensi karakteristik subjek

\begin{tabular}{lcc}
\hline \multicolumn{1}{c}{ Jenis karakteristik subjek } & Frekuensi & Persen (\%) \\
\hline IMT : & 16 & 84,2 \\
Normal (Persentil $\geq 5-\leq 85)$ & 2 & 10,5 \\
Gemuk (Persentil $>85-<95)$ & 1 & 5,3 \\
Obesitas (Persentil $\geq 95)$ & & \\
Persen lemak tubuh : & 7 & 36,8 \\
Kurang (<15\%) & 6 & 31,6 \\
Normal (15-18\%) & 6 & 31,6 \\
Lebih (18\%) & 19 & 100 \\
Kadar hemoglobin : & & \\
Normal (13-16 g/dL) & 3 & 15,8 \\
Asupan energi : & 16 & 84,2 \\
Defisiensi tingkat sedang $(70-79 \%)$ & & \\
Defisiensi tingkat berat $(<70 \%)$ & Asupan karbohidrat : & \\
\hline
\end{tabular}




\begin{tabular}{lcc}
\hline Defisiensi tingkat ringan $(80-89 \%$ & 2 & 10,5 \\
Defisiensi tingkat sedang $(70-79 \%)$ & 4 & 21,1 \\
Defisiensi tingkat berat $(<70 \%)$ & 13 & 68,4 \\
Asupan protein : & & \\
Defisiensi tingkat berat $(<70 \%)$ & 19 & 100 \\
Asupan lemak : & 3 & 15,8 \\
Defisiensi tingkat sedang $(70-79 \%)$ & 16 & 84,2 \\
Defisiensi tingkat berat $(<70 \%)$ & & \\
Daya tahan jantung paru : & 3 & 15,8 \\
Cukup $(38,4-45,1)$ & 7 & 36,8 \\
Baik $(45,2-50,9)$ & 9 & 47,4 \\
Baik sekali $(>51,0)$ & & \\
\hline
\end{tabular}

Berdasar persentil IMT/U untuk usia 2-20 tahun, sebagian besar subjek $(84,2 \%)$ memiliki kategori status gizi normal, sebagian besar subjek $(36,8 \%)$ memiliki persen lemak tubuh yang kurang dan seluruh subjek memiliki kadar hemoglobin normal.

Sebelum diberikan sebagian besar subjek $(84,2 \%)$ memiliki kategori defisiensi energi tingkat berat, 68,4\% subjek memiliki kategori defisiensi karbohidrat tingkat berat, dan seluruh subjek 100\% memiliki kategori defisiensi protein tingkat berat, serta $84,2 \%$ subjek memiliki kategori defisiensi lemak tingkat berat.
Pengukuran daya tahan jantung paru menggunakan metode Cooper Test didapatkan nilai $\mathrm{VO}_{2}$ maksimal, dimana sebagian besar subjek $(84,2 \%)$ memiliki kategori daya tahan jantung paru yang baik.

\section{Perbedaan Hasil Pengukuran Variabel Sebelum dan Sesudah Perlakuan}

Perubahan hasil ukur beberapa variabel sebelum dan sesudah diberikan perlakuan disajikan dalam Tabel 2.

Tabel 2. Perbedaan Hasil Pengukuran Variabel Bebas dan Variabel Kontrol Sebelum dan Sesudah Perlakuan

\begin{tabular}{|c|c|c|c|c|c|}
\hline \multirow{2}{*}{ Variabel } & \multirow{2}{*}{$\mathbf{n}$} & \multicolumn{2}{|c|}{ Rerata \pm SB } & \multirow{2}{*}{$\Delta$} & \multirow[b]{2}{*}{$p$} \\
\hline & & Sebelum & Sesudah & & \\
\hline Asupan energi (kkal) & 19 & $\begin{array}{c}2531,2 \pm \\
517,1\end{array}$ & $\begin{array}{c}4070,7 \pm \\
175,4\end{array}$ & 1539,5 & $0,000^{*}$ \\
\hline $\begin{array}{l}\text { Persentase } \\
\text { karbohidrat }\end{array}$ & 19 & $62,5 \pm 14,2$ & $93,1 \pm 6,9$ & 30,6 & $0,000^{*}$ \\
\hline Persentase asupan protein & 19 & $44,4 \pm 10,4$ & $90,4 \pm 7,4$ & 46,2 & $0,000 *$ \\
\hline Persentase asupan lemak & 19 & $53,2 \pm 14,2$ & $86,5 \pm 86,3$ & 33,3 & $0,000 *$ \\
\hline Indeks massa tubuh $\left(\mathrm{kg} / \mathrm{m}^{2}\right)$ & 19 & $21,9 \pm 2,5$ & $22,1 \pm 2,5$ & 0,2 & $0,000^{*}$ \\
\hline Persen lemak tubuh (\%) & 19 & $16,7 \pm 2,7$ & $17 \pm 2,4$ & 0,3 & 0,126 \\
\hline Kadar hemoglobin $(\mathrm{g} / \mathrm{dL})$ & 19 & $14,8 \pm 0,7$ & $15,1 \pm 0,8$ & 0,3 & 0,211 \\
\hline
\end{tabular}

Tabel 2 menunjukkan terdapat perbedaan rerata asupan energi, karbohidrat, protein, dan lemak yang bermakna sebelum dan sesudah perlakuan. Sebagian besar subjek $(68,4 \%)$ memiliki kategori asupan energi normal, $73,7 \%$ subjek memiliki kategori asupan karbohidrat normal, 52,6\% subjek memiliki kategori defisiensi protein tingkat ringan, dan $52,6 \%$ subjek memiliki kategori defisiensi lemak tingkat ringan.
Terdapat perbedaan rerata indeks massa tubuh yang bermakna sebelum dan sesudah perlakuan. Sebagian besar subjek $(84,2 \%)$ memiliki kategori status gizi normal. Hasil pengukuran persen lemak tubuh sesudah perlakuan menunjukkan tidak terdapat perbedaan rerata persen lemak tubuh sebelum dan sesudah perlakuan dikarenakan nilai $\mathrm{p}=0,126$. Sebagian besar subjek $(63,2 \%)$ memiliki kategori persen lemak tubuh normal. Hasil pengukuran kadar 
hemoglobin sesudah perlakuan menunjukkan tidak terdapat perbedaan kadar hemoglobin sebelum dan sesudah perlakuan, dimana nilai $\mathrm{p}=0,211$ dan seluruh subjek memiliki kadar hemoglobin normal..
Tabel 3 menunjukkan perbedaan hasi pengukuran daya tahan jantung paru sebelum dan sesudah perlakuan.

Tabel 3. Perbedaan Hasil Pengukuran Variabel Dependent Sebelum dan Sesudah Perlakuan

\begin{tabular}{|c|c|c|c|c|}
\hline Pengukuran & $\mathbf{n}$ & $\begin{array}{c}\text { Median } \\
\text { (Minimal-Maksimal) }\end{array}$ & $\Delta$ & $p$ \\
\hline $\begin{array}{l}\text { Daya tahan jantung paru } \\
\text { sebelum }(\mathrm{ml} / \mathrm{kg} \mathrm{BB} / \text { menit }) \\
\text { Daya tahan jantung paru } \\
\text { sesudah (ml/kg BB/menit) }\end{array}$ & 19 & $\begin{array}{l}50,08(38,79-53,09) \\
50,08(41,92-60,47)\end{array}$ & 1,2 & $0,044 *$ \\
\hline
\end{tabular}

Hasil pengukuran daya tahan jantung paru didapatkan bahwa data tidak berdistribusi normal sehingga dilakukan uji statistik nonparametrik dengan uji Wilcoxon, hasilnya menunjukan bahwa terdapat perbedaan rerata daya tahan jantung paru yang bermakna sebelum dan sesudah perlakuan dimana nilai $\mathrm{p}=0,044$ dan sebagian besar subjek
(94,8\%) memiliki kategori daya tahan jantung paru baik.

\section{Hubungan antara Variabel Bebas dan Kontrol dengan Variabel Terikat}

Tabel 4 menunjukkan hubungan antara variabel bebas dan kontrol dengan variabel terikat.

Tabel 4. Hubungan variabel bebas dan kontrol dengan variabel terikat

\begin{tabular}{lcc}
\hline \multicolumn{1}{c}{ Variabel } & $\mathbf{n}$ & $\boldsymbol{p}$ \\
\hline$\Delta$ Asupan energi & 19 & 0,657 \\
$\Delta$ Persen asupan & 19 & 0,686 \\
karbohidrat & & 0,104 \\
$\Delta$ Persen asupan protein & 19 & 0,653 \\
$\Delta$ Persen asupan lemak & 19 & $0,028^{*}$ \\
$\Delta$ IMT & 19 & 0,272 \\
$\Delta$ Persen lemak tubuh & 19 & 0,076 \\
$\Delta$ Kadar hemoglobin & 19 &
\end{tabular}

*Korelasi Pearson, memiliki hubungan bermakna $(\mathrm{p}<0,05)$

Hasil uji korelasi didapatkan hasil bahwa variabel yang memiliki hubungan bermakna dengan daya tahan jantung paru adalah indeks massa tubuh.
Variabel yang Berpengaruh terhadap Daya Tahan Jantung Paru

Analisis multivariate menggunakan uji regresi linier ganda, yang digunakan untuk mengukur besarnya pengaruh antara dua variabel atau lebih variabel terhadap satu variabel terikat. ${ }^{10}$

Tabel 5. Variabel yang Berpengaruh terhadap Daya Tahan Jantung Paru

\begin{tabular}{|c|c|c|c|}
\hline Variabel & Koefisien & Koefisien korelasi & $p^{*}$ \\
\hline$\Delta$ Asupan protein & 0,058 & 0,266 & 0,193 \\
\hline $\begin{array}{l}\Delta \text { Indeks massa } \\
\text { tubuh }\end{array}$ & $-6,463$ & $-0,468$ & $0,03 *$ \\
\hline $\begin{array}{ll}\Delta & \text { Kadar } \\
\text { hemoglobin } & \end{array}$ & 0,984 & 0,372 & 0,076 \\
\hline
\end{tabular}

Variabel terikat : daya tahan jantung paru

*uji koefisien regresi linier ganda $(\mathrm{p}<0,05)$ 
Hasil uji analisis multivariate dengan regresi linier ganda diperoleh bahwa variabel yang mempengaruhi daya tahan jantung paru adalah indeks massa tubuh dengan nilai $\mathrm{p}=0,03$.

\section{PEMBAHASAN}

Penelitian ini menggunakan subjek sebanyak 19 orang yang tergabung dalam satu kelompok perlakuan. Rerata usia subjek yakni 17,4 $\pm 1,0$ tahun dengan usia termuda adalah 15,1 tahun dan tertua adalah 18,6 tahun. Hasil pengukuran antropometri didapatkan rerata tinggi badan subjek adalah $172,1 \pm 4,2 \mathrm{~cm}$, berat badan $64,9 \pm 8,1 \mathrm{~kg}$, dan indeks massa tubuh $21,9 \pm 2,5 \mathrm{~kg} / \mathrm{m}^{2}$. Pada penelitian ini selama 11 hari subjek mendapat perlakuan berupa pemberian makanan dengan ratarata total energi sebesar 4432,6 kkal, karbohidrat $678,8 \mathrm{~g}$, protein 136,7 g dan lemak 146,6 g. Makanan yang diberikan selama sebelas hari terdiri dari tiga kali makan utama dan tiga kali snack. Snack diberikan pagi hari pukul 09.00, sore hari pukul 15.00, dan malam hari pukul 19.00.

Asupan zat gizi dibutuhkan untuk penyediaan energi pada saat seorang atlet melakukan berbagai aktivitas fisik. ${ }^{8}$ Ketersediaan zat gizi di dalam tubuh juga akan berpengaruh terhadap kemampuan daya tahan jantung paru. ${ }^{6}$ Daya tahan jantung paru merupakan komponen terpenting dari kesegaran jasmani, dimana daya tahan jantung paru dapat diukur melalui kadar $\mathrm{VO}_{2}$ maksimal. $^{2}$ Daya tahan jantung paru adalah kemampuan fungsional sistem jantung, paru dan pembuluh darah saat melakukan aktivitas untuk mengambil oksigen secara optimal dan mensuplai oksigen ke seluruh tubuh terutama pada jaringan aktif agar dapat digunakan untuk proses metabolisme tubuh. ${ }^{11}$

Menurut studi yang dilakukan di Yogyakarta diketahui bahwa apabila asupan energi cukup maka tingkat kebugaran jantung paru baik. ${ }^{12}$ Asupan zat gizi yang seimbang dapat diperoleh melalui pengaturan makan secara tepat. Pengaturan makan diperlukan untuk memenuhi kualitas dan kuantitas gizi pada saat masa latihan, bertanding maupun pemulihan yaitu dengan memenuhi jumlah energi dan komposisi zat gizi secara seimbang sesuai dengan kebutuhan individual setiap harinya. ${ }^{13}$

Sebelum diberikan perlakuan rerata asupan energi subjek adalah $2531,2 \pm 517,1 \mathrm{kkal}$, dan sebagian besar subjek $(84,2 \%)$ memiliki kategori defisiensi energi tingkat berat. Berdasar perhitungan didapatkan bahwa rerata kebutuhan energi subjek sebesar 4469,7 $\pm 367,9$ kkal. Hasil food recall sebelum perlakuan menunjukkan bahwa atlet lebih sering mengkonsumi makanan jajanan diluar kantin asrama seperti gorengan. Kebiasaan jajan ini mengakibatkan asupan energi subjek menjadi kurang karena jajanan yang biasa dimakan oleh subjek hanya memberikan rasa kenyang tanpa menyumbang zat gizi yang berarti.

Pemberian makanan sesuai dengan kebutuhan energi subjek selama 11 hari mengakibatkan kenaikan asupan makan subjek dimana rerata asupan subjek menjadi 4070,7 \pm 175,4 kkal. Persentase pemenuhan asupan makan subjek selama penelitian adalah 91,8\%, dimana sebagian besar subjek $(68,4 \%)$ memiliki kategori asupan energi normal. Selama penelitian berlangsung subjek selalu dipantau asupan makanannya, dan sebelum pemberian perlakuan subjek telah dihimbau untuk mengurangi makanan jajanan.

Pada penelitian ini didapatkan hasil bahwa asupan energi tidak berhubungan dengan daya tahan jantung paru. Hasil ini sebanding dengan penelitian pada atlet di Jakarta bahwa tidak terdapat hubungan bermakna antara asupan energi dengan kapasitas oksigen maksimal. ${ }^{14}$ Hal ini dikarenakan kemampuan tubuh menggunakan oksigen secara maksimal ditentukan oleh banyak faktor selain asupan makan diantaranya adalah faktor latihan dan faktor fungsi kerja organ tubuh. ${ }^{15}$ Latihan aerobik secara teratur yang dilakukan oleh subjek selama penelitian berlangsung menyebabkan peningkatan nilai $\mathrm{VO}_{2}$ maksimal. Latihan aerobik dapat meningkatkan nilai $\mathrm{VO}_{2}$ maksimal dikarenakan saat melakukan latihan tersebut suplai oksigen ke otot meningkat sehingga memberi kemampuan pada atlet untuk melakukan aktivitas olahraga dengan waktu yang lebih lama dan konsumsi oksigen maksimal menjadi lebih besar.

Karbohidrat merupakan sumber energi utama untuk memenuhi kebutuhan gizi bagi atlet sepak bola. Asupan karbohidrat untuk atlet diperlukan untuk membentuk glikogen hati dan otot. ${ }^{1}$ Gambaran asupan karbohidrat subjek dalam penelitian ini menunjukkan bahwa sesudah diberikan perlakuan, rerata persentase asupan karbohidrat mengalami peningkatan yang bermakna, dimana reratanya sebelumnya adalah $62,53 \pm 14,26 \%$ dan sesudah adalah 93,15 $\pm 6,98$ $\%$. Pada penelitian ini didapatkan hasil bahwa 
asupan karbohidrat tidak memiliki hubungan yang bermakna dengan daya tahan jantung paru, dimana nilai $\mathrm{p}=0,686$. Hal ini berbanding terbalik dengan dengan penelitian di Jakarta yang menyebutkan ada hubungan antara asupan karbohidrat dengan nilai kapasitas oksigen maksimal. ${ }^{14}$ Tidak adanya hubungan antara asupan karbohidrat dan daya tahan jantung paru disebabkan karena adanya faktor lain yang lebih mempengaruhi daya tahan jantung paru yaitu latihan aerobik rutin yang dijalani oleh subjek.

Pada penelitian ini rerata persentase asupan protein sebelum dan sesudah perlakuan memiliki perbedaan yang bermakna, dimana rerata persentase asupan protein sesudah diberi perlakuan menjadi lebih baik yakni 90,45 $\pm 7,45 \%$. Bagi atlet sepak bola yang masih remaja, protein dibutuhkan untuk mendukung pertumbuhan dan pembentuk tubuh guna mencapai tinggi badan yang optimal, selain itu protein bermanfaat untuk pembentukan sel darah merah, pertahanan tubuh terhadap penyakit, serta sintesis jaringan tubuh. ${ }^{1}$

Pada penelitian ini didapatkan hasil bahwa asupan protein tidak mempengaruhi daya tahan jantung paru dengan nilai $\mathrm{p}=0,461$. Hasil ini sebanding dengan penelitian di Padang dimana pola konsumsi protein tidak memiliki hubungan dengan daya tahan jantung paru. ${ }^{16}$ Tidak adanya pengaruh asupan protein terhadap daya tahan jantung paru terlihat dari 10 subjek $(52,6 \%)$ yang memiliki kategori defisiensi protein tingkat ringan, 4 subjek mengalami kenaikan nilai VO2 maksimal, 2 subjek tetap, dan 4 subjek mengalami penurunan, sehingga tidak terdapat pengaruh dari asupan protein terhadap daya tahan jantung paru.

Gambaran asupan selama diberikan perlakuan menunjukkan terdapat perbedaan rerata persentase asupan lemak yang bermakna sebelum dan sesudah perlakuan. Lemak merupakan zat gizi yang menghasilkan energi paling besar dan merupakan sumber energi yang penting untuk kontraksi otot selama olahraga endurance. ${ }^{1}$ Latihan akan meningkatkan kapasitas otot dalam menggunakan lemak sebagai sumber energi, dimana metabolisme lemak yang meningkat saat melakukan olahraga dengan durasi lama memiliki efek dalam menghemat pemakaian glikogen dan memperbaiki ketahanan fisik. ${ }^{17}$

Pada penelitian ini, didapatkan hasil bahwa asupan lemak tidak berhubungan dengan daya tahan jantung paru dengan nilai $p=0,653$. Hasil ini sebanding dengan penelitian di Padang yang melihat hubungan antara pola konsumsi lemak terhadap daya tahan jantung paru, dimana asupan lemak tidak mempengaruhi daya tahan jantung paru. ${ }^{18} \mathrm{Hal}$ ini disebabkan daya tahan jantung paru tidak hanya dipengaruhi oleh asupan makan namun ada faktor lain yang dapat meningkatkan daya tahan jantung paru berupa latihan aerobik dan latihan sepak bola yang rutin dilakukan selama 11 hari dalam seminggu.

Sesudah diberikan perlakuan, subjek penelitian mengalami kenaikan rerata indeks massa tubuh yakni sebesar $22,1 \pm 2,5 \mathrm{~kg} / \mathrm{m}^{2}$, dimana sebagian besar subjek $(84,2 \%)$ memiliki status gizi normal. Kenaikan rerata indeks massa tubuh ini dipengaruhi oleh kenaikan berat badan yang disebabkan oleh asupan makan yang meningkat setelah diberikan perlakuan yaitu sebesar 1539,5 kkal. Peningkatan berat badan pada 19 subjek yaitu sebesar 100-1600 gram.dan terdapat pengaruh indeks massa tubuh terhadap daya tahan jantung paru dengan nilai $p=0,03$. Hasil ini sejalan dengan hasil penelitian di Padang yang menunjukkan bahwa status gizi berupa indeks massa tubuh berhubungan dengan daya tahan jantung paru atlet. ${ }^{18}$ Diketahui bahwa indeks massa tubuh yang baik hasil dari olahraga akan memperbaiki pengambilan oksigen maksimum. ${ }^{17,19}$ Hasil penelitian lainnya menunjukkan bahwa terdapat perbedaan nilai $\mathrm{VO}_{2}$ maksimal antara subjek penelitian yang memiliki status gizi normal dan kurang, dimana dari 50 subjek penelitian, 39 subjek dengan status gizi normal memiliki nilai $\mathrm{VO}_{2}$ maksimal rata-rata adalah $41,88 \mathrm{~mL} / \mathrm{kg}$ $\mathrm{BB} /$ menit, sedangkan pada 11 subjek dengan status gizi kurang nilai $\mathrm{VO}_{2}$ maksimal rata-rata adalah $37,83 \mathrm{~mL} / \mathrm{kg} \mathrm{BB} /$ menit. $^{15}$

Hubungan antara status gizi dan $\mathrm{VO}_{2}$ maksimal yaitu karena status gizi lebih ditentukan oleh berat badan. Seseorang dengan berat badan yang normal memiliki cadangan energi yang lebih besar sehingga konsumsi oksigen maksimal lebih besar. Konsumsi oksigen maksimal ditentukan terutama oleh cadangan energi dan fungsi mitokondria, dimana mitokondria otot banyak memproduksi ATP sebagai sumber energi. Kemampuan tubuh menggunakan oksigen maksimal juga dipengaruhi oleh energi aerobik, yaitu pemecahan ATP menjadi energi dengan bantuan $\mathrm{O}_{2}$ sehingga dengan indeks massa tubuh yang melebihi normal maka makin rendah kemampuan tubuh untuk menggunakan oksigen secara maksimal. ${ }^{15,20}$

Atlet sepak bola harus memiliki ukuran tubuh yang ideal, dimana ukuran tubuh atlet diukur berdasarkan persentase lemak tubuh. Proporsi ukuran tubuh atlet biasanya berbeda pada setiap 
cabang, pada atlet sepak bola ukuran tubuh harus seimbang antara massa otot dan massa lemak. ${ }^{1}$ Penelitian di Padang menunjukkan bahwa variabel persentase lemak tubuh memiliki pengaruh terhadap daya tahan jantung paru. ${ }^{18}$ Penelitian lainnya juga menunjukkan bahwa atlet dengan nilai persen lemak tubuh yang lebih memiliki nilai $\mathrm{VO}_{2}$ maksimal yang kurang. ${ }^{6}$ Semakin tinggi nilai persentase lemak tubuh, semakin kecil nilai kapasitas $\mathrm{VO}_{2}$ maksimal seseorang. Hal ini dikarenakan pada proses fisiologis, kapasitas pengambilan oksigen didukung oleh kardiorespirasi serta kekuatan dan ketahanan otot, tingginya lemak tubuh akan menurunkan persentase otot sehingga mengurangi kerja aerobik, selain itu persen lemak tubuh yang tinggi akan meningkatkan kebutuhan akan sistem kardiovaskuler. ${ }^{6,21}$

Pada penelitian ini sebelum diberikan perlakuan $36,8 \%$ subjek penelitian memiliki persen lemak tubuh yang kurang, 31,6\% memiliki persen lemak tubuh yang normal, 31,6\% memiliki persen lemak tubuh lebih dan sesudah diberi perlakuan sebagian besar subjek $(63,2 \%)$ memiliki kategori persen lemak tubuh normal. Perubahan kriteria persen lemak tubuh pada sebagian besar subjek disebabkan oleh asupan makan yang meningkat dimana selama penelitian subjek diberi asupan karbohidrat $55-60 \%$, protein $15-20 \%$ dan lemak 20-30\% dari total kebutuhan energi. Hasil pengukuran persen lemak tubuh sebelum dan sesudah diberi perlakuan dalam pada penelitian ini menunjukkan perbedaan yang tidak bermakna dengan nilai $p=0,126$. Selain itu didapatkan hasil bahwa tidak terdapat hubungan antara persen lemak tubuh dan daya tahan jantung paru dengan nilai $\mathrm{p}=0,272$. Persen lemak tubuh tidak mempengaruh daya tahan jantung paru pada penelitian ini dikarenakan daya tahan jantung paru juga dipengaruhi oleh faktor lain berupa latihan fisik. Selama penelitian subjek rutin menjalani latihan sebanyak 11 kali dalam seminggu. Diketahui bahwa atlet yang rutin melakukan latihan akan memiliki nilai $\mathrm{VO}_{2}$ maksimal yang lebih tinggi. ${ }^{22}$

Pengukuran kadar hemoglobin pada penelitian ini menggunakan metode cyanmethemoglobin dan hasilnya seluruh subjek baik sebelum maupun sesudah diberi perlakuan memiliki kadar hemoglobin normal yang berada pada rentang 13-16 g/dL. Nilai $\mathrm{VO}_{2}$ maksimal memiliki kaitan erat dengan sistem transportasi oksigen yang diperlukan tubuh untuk menghasilkan energi melalui proses metabolisme di mitokondria. Oksigen yang diambil di paru-paru diangkut oleh hemoglobin dan dilepaskan ke jaringan aktif. Semakin tinggi kadar hemoglobin, proses transport oksigen ke jaringan akan semakin optimal. $^{23}$ Hemoglobin sebagai pengangkut oksigen berperan dalam pengaturan tekanan oksigen dalam jaringan, sehingga akan menentukan pemakaian dan pelepasan oksigen dalam jaringan. ${ }^{6}$

Pada penelitian ini tidak terdapat perbedaan kadar hemoglobin sebelum dan sesudah diberi perlakuan dengan nilai $p=0,211$. Selain itu juga didapatkan hasil bahwa kadar hemoglobin tidak mempengaruhi daya tahan jantung paru. Kemungkinan hal ini disebabkan karena seluruh subjek memiliki kategori kadar hemoglobin yang normal sehingga tidak terdapat pengaruh kadar hemoglobin yang signifikan terhadap peningkatan daya tahan jantung paru.

Hasil pengukuran daya tahan jantung paru sebelum dan sesudah diberikan perlakuan menunjukkan perbedaan yang bermakna, dimana daya tahan jantung paru meningkat dengan nilai minimal dan maksimal sebelumnya adalah 38,79$53,09 \mathrm{~mL} / \mathrm{kg} \mathrm{BB} /$ menit dan sesudah adalah 41,92$60,47 \mathrm{~mL} / \mathrm{kg} \mathrm{BB} /$ menit. Nilai $\mathrm{VO}_{2}$ maksimal telah dikatakan baik apabila berada dalam rentang 45,2$50,9 \mathrm{~mL} / \mathrm{kg} \mathrm{BB} /$ menit. $^{24}$ Sebagian besar subjek $(94,8 \%)$ memiliki kategori daya tahan jantung paru baik, dimana rerata daya tahan jantung paru sesudah perlakuan adalah $50,9 \pm 3,9 \mathrm{~mL} / \mathrm{kg}$ $\mathrm{BB} /$ menit.

Kelemahan dalam penelitian ini adalah jumlah sampel yang terbatas, serta tidak dilakukannya pengukuran aktivitas fisik secara teliti. Selain itu pengukuran persen lemak tubuh menggunakan BIA injak tidak dapat mengukur persen lemak tubuh secara keseluruhan.

\section{SIMPULAN}

Rerata asupan energi, karbohidrat, protein, dan lemak setelah diberi perlakuan mengalami peningkatan yang bermakna. Sebagian besar subjek $(68,4 \%)$ memiliki kategori asupan energi normal, $73,7 \%$ subjek memiliki kategori asupan karbohidrat normal, 52,6\% subjek memiliki kategori defisiensi protein tingkat ringan, dan 52,6\% subjek memiliki kategori defisiensi lemak tingkat ringan. Pada penelitian ini didapatkan hasil tidak terdapat pengaruh asupan energi, karbohidrat, protein, dan lemak terhadap daya tahan jantung paru atlet.

Sebagian besar subjek $(84,2 \%)$ memiliki status gizi normal, dimana sesudah diberi 
perlakuan terdapat perbedaan rerata indeks massa tubuh yang bermakna. Sebanyak 63,2\% subjek memiliki persen lemak tubuh yang normal, namun tidak terdapat perbedaan antara sebelum dan sesudah perlakuan. Semua subjek memiliki kadar hemoglobin normal baik sebelum maupun sesudah perlakuan.

Pengukuran daya tahan jantung paru didapatkan hasil bahwa terdapat perbedaan bermakna antara sebelum dan sesudah perlakuan, dimana sebagian besar subjek $(94,8 \%)$ memiliki kategori daya tahan jantung paru yang baik. Variabel yang mempengaruhi daya tahan jantung paru adalah indeks massa tubuh.

\section{SARAN}

Atlet disarankan untuk mengkosumsi makanan sesuai dengan kebutuhan hariannya agar performa tetap terjaga. Selain itu kebutuhan energi atlet disesuaikan dengan latihan dan aktivitas fisik yang dilakukan sehari-hari.

\section{UCAPAN TERIMA KASIH}

Puji syukur kepada Allah SWT dan terima kasih kepada dosen pembimbing yang telah membimbing penelitian ini serta kepada dosen penguji yang telah memberikan masukan dan saran dalam penelitian ini. Ucapan terima kasih juga disampaikan kepada subjek penelitian serta pelatih sepak bola di Pusat Pendidikan Latihan Pelajar (PPLP) Jawa Tengah serta Dinas Pemuda dan Olahraga Jawa Tengah yang telah bekerja sama dan membantu terlaksananya penelitian ini. Selain itu, ucapan terima kasih juga disampaikan kepada keluarga dan teman-teman yang telah memberikan doa, motivasi dan dukungan bagi penelitian ini.

\section{DAFTAR PUSTAKA}

1. Husaini MA, Dadang AP, Anie K, Dangsina M, Didit D. Gizi atlet sepak bola. Jakarta : Depkes R.I. Dirjen Kesehatan Masyarakat Direktorat Gizi Masyarakat; 2002. p.1-2.

2. Hoff J, Wisloff U, Engen LC, Kemi OJ, Helgerud J. Soccer specific aerobik endurance training. British Journal of Sports Medicine. [serial online] 2002 [dikutip 2012 Mar 3]; 36; p.218-221. Tersedia URL:

http://bjsportmed.com/content/36/3/218.full.pdf+ht $\underline{\mathrm{ml}}$

3. Levine $\mathrm{BD} . \mathrm{VO}_{2}$ max : what do we know, and what do we still need to know? Journal Physiology Society. [serial online] 2008 [dikutip 2012 Apr 21]; 586(1); p.25-34. Tersedia URL: http://jp.physoc.org/content/586/1/25.full.pdf+html

4. Utoro BF. Pengaruh penerapan carbohydrate loading modifikasi terhadap kesegaran jasmani atlet sepak bola. [artikel penelitian] Program Studi Ilmu Gizi Fakultas Kedokteran, Universitas Diponegoro Semarang; 2011.

5. Almatsier S. Prinsip dasar ilmu gizi. Jakarta : Gramedia Pustaka Utama; 2001. p.4-9.

6. Widiastuti PA, Kushartanti BMW, Kandarina IBJ. Pola makan dan kebugaran jasmani atlet pencak silat selama pelatihan daerah pekan olahraga nasional XVII Provinsi Bali tahun 2008. Jurnal Gizi Klinik Indonesia. [serial online] 2009 [dikutip 2012 Apr 22]; 6 (1); p.13-20. Tersedia URL: http://isjd.pdii.lipi.go.id/admin/jurnal/61091320.pdf

7. Heather HF, Lisa C, Alan EM. Endurance and ultra-endurance athletes. In: Practical applications in sport nutrition. Boston : Jones and Bartlett Publisher; 2006. p.360-97.

8. Hasan MS. Kesegaran jasmani olahragawan sepak bola pra-pubertas. Jurnal Iptek Olahraga. [serial online] 2008 September [dikutip 2012 Jan 25]; 10(3) ; p.188-202. Tersedia : URL:http://iptekor.com/doc/10_3_3.pdf

9. Immawati A. Pengaruh pemberian sport drink terhadap performa dan tes keterampilan pada atlet sepak bola usia 15-18 tahun. [artikel penelitian] Program Studi Ilmu Gizi Fakultas Kedokteran, Universitas Diponegoro Semarang; 2011.

10. Sastroasmoro S, Ismael S. Dasar-dasar metodologi penelitian klinis edisi ke-3. Jakarta: Sagung Seto; 2008. p.88-269.

11. Karim F. Panduan kesehatan olahraga bagi petugas kesehatan. Jakarta : Departemen Kesehatan, Perhimpunan Pembina Kesehatan Olahraga Republik Indonesia; 2002. p.13.

12. Fajarwati S. Hubungan asupan energi dengan tingkat kebugaran paru jantung $\left(\mathrm{VO}_{2} \max \right)$ peserta senam aerobik di sanggar senam dan fitness centre Kartika Dewi Yogyakarta. [penelitian kesehatan] 2006 [dikutip 2012 Feb 12]. Tersedia URL : http://digilib.litbang.depkes.go.id/go.php?id=ikpkb ppk-gdl-res-2007-sulastrifa2374\&q=epidemiologis\&PHPSESSID $=716 \mathrm{f} 44 \mathrm{c} 611$ 06da5ce2968283822a09e3

13. Sedyanti. Pedoman pelatihan gizi olahraga untuk prestasi. Jakarta : Depkes R.I. Dirjen Kesehatan Masyarakat Direktorat Gizi Masyarakat; 2000. p.77-84

14. Ita. Hubungan antara asupan energi dengan indeks massa tubuh (imt), persen lemak tubuh, dan kapasitas oksigen maksimal $\left(\mathrm{VO}_{2}\right.$ maks $)$ atlet pada periode latihan di pusat pelatihan klub bola basket satria muda britama Jakarta. [skripsi] Program Studi Gizi Kesehatan Fakultas Kedokteran Universitas Gajah Mada; 2009.

15. Mongsidi W. Analisis status gizi dan hubungannya dengan kemampuan tubuh menggunakan oksigen secara maksimal. Indonesian Scientific Journal Database. [serial online] 2007 [dikutip 2012 Agu 5]; 14 (2); p.63-67. Tersedia URL : 
http://isjd.pdii.lipi.go.id/admin/jurnal/142076367.p $\underline{\mathrm{df}}$

16. Kusumawati M. Hubungan antara pola konsumsi protein dan fe dengan daya tahan jantung paru atlet sepak bola PS. Semen Padang tahun 2003. [tesis] Universitas Gadjah Mada; 2004.

17. Amani AR, Somchit MN, Konting MM. Relationship between body fat percent and maximal oxygen uptake among young adults. Journal of American Science. [serial online] 2010 [dikutip 2012 Apr 22]; 6 (4); p.1-4. Tersedia URL: http://www.jofamericanscience.org/journals/amsci/ am0604/01 2002_physiology am0604_1 4.pdf

18. Ferry. Hubungan antara pola konsumsi karbohidrat, lemak dan faktor lainnya dengan daya tahan jantung paru atlet sepak bola Ps. Semen Padang divisi utama PSSI Liga Bank Mandiri IX Tahun 2003. [tesis] Program Studi S2 Ilmu Kesehatan Masyarakat, Universitas Gajah Mada; 2004.

19. Dyrstad SM, Aandstad A, Hallen J. Aerobik fitness in young Norwegian men : a comparison between 1980 and 2002. Scandinavian Journal of Medicine and Science in Sports. [serial online] 2005 [dikutip 2012 Apr 23]; p.1-5. Tersedia URL :

http://byttpassord.nih.no/documents_intranett/Seksj on $\% 20$ for $\% 20$ fysisk\%20prestasjonsevne/FOU/Publ ikasjoner\%202005/Dyrstad_Aandstad_Hall\%C3\% A8n_2005_Aerobik\%20fitness\%20in\%20young\%2 0comparison\%20between \%201998\%20and\%20200 2\%27.pdf

20. Huldani. Status gizi mempengaruhi nilai konsumi oksigen maksimal (VO2 maks) siswa Pondok Pesantren Darul Hijrah. Jurnal Elektronik CDK 191. [serial online] 2012 [dikutip 2012 Mei 23]; 39(3); p.194-5. Tersedia URL :

http://www.kalbemed.com/Portals/6/11_191Status $\% 20 \mathrm{Gizi} \% 20 \mathrm{Mempengaruhi} \% 20 \mathrm{Konsumsi} \% 20 \mathrm{Oks}$ igen\%20Maksimal.pdf

21. Komarudin. Model statistik regresi dengan variabel non -latihan sebagai prediktor kapasitas aerobik (VO2 maksimal). Jurnal Universitas Negeri Yogyakarta. [serial online] 2010 [dikutip $2012 \mathrm{Agu}$ 5]. Tersedia URL :

http://staff.uny.ac.id/sites/default/files/penelitian/K omarudin,\%20M.A./Model\%20Statistik\%20Regres i.pdf

22. Andhikarmika U. Pengaruh latihan fisik terprogram terhadap perubahan nilai konsumsi oksigen maksimal $\left(\mathrm{VO}_{2} \max \right)$ pada siswi sekolah bola voli tugu muda Semarang usia 11-13 tahun. [karya tulis ilmiah] Program Pendidikan Sarjana Fakultas Kedokteran, Universitas Diponegoro Semarang; 2009.

23. Huldani. Pengaruh kadar hemoglobin dan jenis kelamin terhadap konsumsi oksigen maksimum siswa-siswi Pesantren Darul Hijrah. Jurnal Elektronik CDK 180. [serial online] September, 2010 [dikutip 2012 Apr 23]; p.509-11. Tersedia URL:
http://www.kalbe.co.id/files/cdk/files/10_180Penga ruhkadarhemoglobin.pdf/10_180Pengaruhkadarhe moglobin.pdf

24. Kenny M, J Helgerud, R MacDonald, J Hoff. Physiological adaptation to soccer specific endurance training in professional youth soccer players. British Journal Sports Medicine. [serial online] 2005 [dikutip 2012 Mar 15]; 39(5); p.273-7. Tersedia URL:

http://www.msscentershop.info/content/39/5/273.fu $\underline{\text { ll.pdf }+ \text { html }}$ 